\title{
A concise cannabis guide: History, laws and regulations
}

1937

The Marijuana Tax Act is signed into federal law. The Act, though it does not explicitly outlaw cannabis, establishes tight restrictions that effectively prohibit its sale and use.

1970

The Controlled Substances Act, a

federal law, establishes schedules that categorize drugs according to their perceived medical utility and potential for abuse. Cannabis, along with heroin and LSD, is assigned to the highly restrictive Schedule I. As a result, even scientists face great difficulty in obtaining cannabis for research purposes.

1996

California voters approve the

Compassionate Use Act, legalizing medical cannabis in the state. For the next 19 years, California's medical cannabis industry operates essentially unregulated.

2015

The California Legislature passes

and Gov. Brown signs the Medical Marijuana Regulation and Safety Act (later renamed the "Medical Cannabis Regulation and Safety Act"). The law establishes a threeagency regulatory structure for cannabis activities.

2016

California voters approve

Proposition 64, the Adult Use of Marijuana Act, which legalizes on the state level the cultivation, possession, sale and use of recreational cannabis.

The Legislature passes the

Medicinal and Adult-Use Cannabis Regulation and Safety Act, integrating Proposition 64 and the Medical Cannabis Regulation and Safety Act, thus establishing a combined regulatory system for medical and adult-use cannabis in California.

\section{California's cannabis regulators}

\begin{tabular}{|l|l|l|l|}
\hline Agency & $\begin{array}{l}\text { Bureau of Cannabis } \\
\text { Control }\end{array}$ & $\begin{array}{l}\text { Manufactured } \\
\text { Cannabis Safety } \\
\text { Branch }\end{array}$ & $\begin{array}{l}\text { CalCannabis } \\
\text { Cultivation Licensing }\end{array}$ \\
\hline $\begin{array}{l}\text { Parent } \\
\text { organization }\end{array}$ & $\begin{array}{l}\text { Department of } \\
\text { Consumer Affairs }\end{array}$ & $\begin{array}{l}\text { Department of } \\
\text { Public Health }\end{array}$ & $\begin{array}{l}\text { Department of Food } \\
\text { and Agriculture }\end{array}$ \\
\hline $\begin{array}{l}\text { Primary } \\
\text { activities }\end{array}$ & $\begin{array}{l}\text { Licenses and } \\
\text { regulates cannabis } \\
\text { retailers, distributors, } \\
\text { microbusinesses, } \\
\text { testing laboratories } \\
\text { and temporary } \\
\text { events; is designated } \\
\text { as state's lead } \\
\text { cannabis agency }\end{array}$ & $\begin{array}{l}\text { Regulates } \\
\text { manufacturing of } \\
\text { cannabis products } \\
\text { such as extracts and } \\
\text { edibles, ensuring } \\
\text { that products are } \\
\text { properly packaged } \\
\text { and labeled and are } \\
\text { free of contaminants }\end{array}$ & $\begin{array}{l}\text { Licenses and } \\
\text { regulates cannabis } \\
\text { cultivators; } \\
\text { implements the } \\
\text { state's track-and- } \\
\text { trace system, } \\
\text { which follows } \\
\text { the movement of } \\
\text { cannabis from seed } \\
\text { to sale }\end{array}$ \\
\hline
\end{tabular}

\section{What cannabis activities are allowed — and where?}

While state law provides for the cultivation and manufacture of cannabis and its sale in retail stores, cities and counties may pass ordinances banning these activities. Localities without explicit bans on cannabis activities also may effectively ban them through, for example, zoning ordinances (certain activities, such as delivery of cannabis from a different jurisdiction, may not be banned). The table below gives examples of what is allowed in a few cities and counties.

\begin{tabular}{|l|c|c|c|}
\hline Location & $\begin{array}{c}\text { Commercial } \\
\text { cultivation }\end{array}$ & $\begin{array}{c}\text { Adult-use } \\
\text { retail stores }\end{array}$ \\
\hline State of California & Allowed & Allowed & Allowed \\
\hline Selected cities & & & \\
\hline Anaheim & Prohibited & Prohibited & Prohibited \\
\hline Portola & Prohibited & Prohibited & Prohibited \\
\hline
\end{tabular}

Selected counties

\begin{tabular}{lccc} 
Kern County & Prohibited & Prohibited & Prohibited \\
\hline Orange County & Prohibited & Prohibited & Prohibited \\
\hline $\begin{array}{l}\text { Santa Barbara } \\
\text { County }\end{array}$ & Allowed & Allowed & Allowed \\
Tehama County & Prohibited & Prohibited & Prohibited \\
\hline
\end{tabular}

\begin{tabular}{|l|l|c|c|}
\hline A city/county split* & \multicolumn{3}{|l|}{} \\
\hline Oakland & Allowed & Allowed & Allowed \\
\hline Alameda County & Allowed & Prohibited & Allowed \\
\hline
\end{tabular}

* Where city and county ordinances differ, the city's ordinance applies within its boundaries.

Online: https://doi.org/10.3733/ca.2019a0022 